Becoming Christian 



\section{Becoming Christian}

The Conversion of

Roman Cappadocia

Raymond Van Dam

$\overline{\text { PENN }}$

University of Pennsylvania Press

Philadelphia 
Copyright $\odot 2003$ University of Pennsylvania Press All rights reserved

Printed in the United States of America on acid-free paper

$\begin{array}{llllllllll}10 & 9 & 8 & 7 & 6 & 5 & 4 & 3 & 2 & 1\end{array}$

Published by

University of Pennsylvania Press

Philadelphia, Pennsylvania 19104-4011

Library of Congress Cataloging-in-Publication Data

Van Dam, Raymond.

Becoming Christian : the conversion of Roman Cappadocia / Raymond Van Dam.

p. cm.

ISBN 0-8122-3738-2 (alk. paper)

Includes bibliographical references and index.

1. Basil, Saint, Bishop of Caesarea, ca. 329-379. 2. Gregory, of Nyssa, Saint, ca. 335-ca. 394. 3. Gregory, of Nazianzus, Saint. 4. Christianity and cultureTurkey-Cappadocia-History. 5. Cappadocia (Turkey)-_Church history. I. Title $B R 185 . V 36 \quad 2003$

$275.64^{\prime} 02-d c 21$ 2003047320

Endpapers: Asia Minor and the Eastern Mediterranean in the fourth century. 
For Jan

"Laughter fills the air; your loving grace surrounds me"

-Bruce Springsteen, Mary's Place 
